\title{
Los socialistas y la insurrección de octubre de 1934
}

\author{
JUAN AVILÉS \\ Catedrático en el Dpto. $\mathrm{H}^{\mathrm{a}}{ }^{\mathrm{a}}$ Contemporánea. UNED \\ The Socialists and the October 1934 Insurrection
}

\begin{abstract}
RESUMEN
Este ensayo analiza el papel del Partido Socialista Obrero Español en los orígenes de la insurrección de octubre de 1934, aplicando la teoría del encuadramiento. Revisa las diferentes interpretaciones de la insurrección propuestas por los estudiosos. Considera los diversos factores que contribuyeron a la construcción por los socialistas del encuadre de acción colectiva que condujo a la insurrección, tales como la interacción entre líderes y seguidores, la concepción marxista de la democracia burguesa, la influencia de la Revolución rusa, la derrota socialista en Alemania y Austria, el optimismo revolucionario de Largo

Caballero y el temor a un golpe derechista. Finalmente discute si el propósito de la insurrección era defender la República, prevenir el triunfo del fascismo y/o establecer un régimen socialista revolucionario.

PALABRAS CLAVE Socialismo español, insurrección de octubre de 1934, teoría del encuadramiento.
\end{abstract}

\begin{abstract}
This essay analyses the role of the Spanish Socialist Workers Party in the origins of the October 1934 insurrection applying the framing theory. It surveys the different interpretations of the insurrection proposed by scholars. It considers the various factors implied in the Socialists' construction of the collective action frame that led to the insurrection, such as the interaction between leaders and followers, the Marxist view of bourgeois democracy, the Spanish insurrectionary tradition, the influence of the Russian Revolution, the Socialist defeat in Germany and Austria, the revolutionary optimism of Largo Caballero and the fear of a rightist coup. Finally it discusses whether the insurrection purpose was defending the Republic, preventing a Fascist regime and/or establishing a revolutionary Socialist regime.
\end{abstract}

KEY WORDS Spanish Socialism, October 1934 Insurrection, Framing Theory. 
La insurrección de octubre de 1934 y en particular el papel que en su génesis jugaron las organizaciones socialistas representa una de las cuestiones más polémicas y difíciles de interpretar en la historia de la Segunda República española. Los socialistas, que habían participado en la fundación de la República y habían formado parte del gobierno hasta un año antes, se alzaron en armas contra las instituciones republicanas. ¿Fue una insurrección preventiva para cerrar el paso al fascismo, una insurrección revolucionaria para establecer una dictadura socialista o una combinación de ambas?

Los hechos en sí mismos son bien conocidos. En julio de 1933, Largo Caballero, ministro todavía en un gobierno de coalición presidido por Azaña, anunció que el objetivo de su partido era la conquista del poder. En septiembre, cuando Lerroux formó un gobierno de concentración republicana sin contar con los socialistas, el comité nacional del PSOE discutió la posibilidad de armarse y preparar un movimiento para la conquista del poder. En enero de 1934, tras la derrota de las izquierdas en las elecciones de noviembre, la ejecutiva socialista decidió preparar un movimiento revolucionario, aunque sin fijar fecha para el mismo; acuerdo que fue suscrito por la ejecutiva de la UGT, a pesar de la oposición de Besteiro. En marzo, la CNT de Asturias formó una alianza revolucionaria con la UGT, que le llevaría a participar en la insurrección. En septiembre se sumó a la alianza revolucionaria el Partido Comunista de España. Y cuando el 4 de octubre se anunció que el nuevo gobierno de Lerroux contaría con tres ministros de la CEDA, el partido de derechas que había sido el más votado en las elecciones del año anterior, se produjo la insurrección. En la mayor parte de España esta fue un fiasco, (incluida Cataluña, donde la insurrección fue protagonizada por el gobierno de la Generalidad, presidido por Companys), pero en Asturias dio lugar a una pequeña guerra civil, que se prolongó durante dos semanas.

Este artículo no se propone analizar el desarrollo de la insurrección, ni la participación en la misma de anarcosindicalistas y comunistas, ni abordará la insurrección paralela del gobierno catalán, sino que se centra en un solo elemento del tema: la decisión de los socialistas de romper con la legalidad republicana, que ellos mismos habían contribuido a fundar tres años antes, e intentar la conquista del poder por la vía de las armas. Para esclarecer los motivos de esa crucial decisión, se analizan el discurso público de la dirección socialista, los debates internos de sus órganos directivos y las medidas prácticas que tomaron para preparar la insurrección. Las fuentes consultadas han sido el diario El Socialista, que constituye una auténtica mina para reconstruir la línea de pensamiento predominante entre los socialistas durante los meses en que se gestó la insurrección, la documentación interna conservada en la Fundación Pablo Iglesias, y algunos documentos inéditos de singular importancia procedentes del archivo de la Guerra Civil en Salamanca. El enfoque utilizado en el análisis responde al concepto de framing (encuadramiento) cada vez más difundido en los estudios sobre movimientos sociales.

\footnotetext{
1 Véase la relación de libros y artículos sobre el tema recopilada en FONSECA, 2003.
} 


\section{BREVE ESTADO DE LA CUESTIÓN: LAS INTERPRETACIONES EN LIZA}

La bibliografía sobre la insurrección de octubre es amplia y en ella pueden encontrarse bastantes referencias a los posibles motivos que indujeron a los socialistas a optar por la insurrección armada y a los objetivos que perseguían con ella ${ }^{1}$. En la breve síntesis que se ofrece a continuación se examinan las principales interpretaciones que se han defendido en los últimos veinticinco años, es decir a partir de 1984, el año del cincuentenario, que dio lugar a varias publicaciones relevantes.

\section{Una insurrección defensiva}

La tesis de que los socialistas lanzaron la insurrección con un propósito básicamente defensivo, para evitar el establecimiento de un régimen autoritario, e incluso contra sus propios deseos, ha sido defendida entre otros por David Ruiz, en un breve libro publicado en 1988. Su argumento es que «la movilización de los trabajadores se presentaba como la única salida política frente a la solución que el presidente de la República dio a la crisis del gobierno radical», porque cualquier otra respuesta a la participación gubernamental de la CEDA «implicaría ineludiblemente propiciar el desencadenamiento por el gobierno recién configurado de una oleada represiva sobre las organizaciones obreras", como había ocurrido en Austria. El movimiento había sido preparado con «un objetivo preventivo», aunque «los más cualificados líderes socialistas no regatearán esfuerzos para componer una nueva imagen radicalizada sirviéndose abusivamente del término revolución en sus manifestaciones externas.» Esas manifestaciones externas tenían un triple propósito: «alertar al presidente de la República sobre la peligrosidad de la estrategia de Gil Robles, intimidar al conglomerado derechista obligándole a la renuncia de sus objetivos y, finalmente, dosificar la incontinencia radical en función de la demanda de los crecientes auditorios obreros y de la fortaleza y cohesión de la propia organización». Pero «la alternativa revolucionaria no era considerada por la dirección nacional del socialismo español en 1934», su proyecto era «de naturaleza defensiva $»^{2}$. Es decir, que la retórica de Largo Caballero no puede servir de base para entender sus propósitos, más moderados de lo que aquella daba a entender.

\section{Una insurrección revolucionaria que dio inicio a la guerra civil}

La tesis, diametralmente opuesta, de que se trató de una insurrección revolucionaria, que no pretendía hacer frente a una inexistente amenaza fascista, sino que se dirigía a la conquista del poder, ha sido planteada por Pío Moa en un libro de 1999. El tono extremadamente polémico que ha ido adquiriendo la obra de Moa

2 RUIZ, D. 1988: 145-146. Cuando este artículo estaba ya en imprenta se publicado otro libro del mismo autor: RUIZ, D. 2008. 
ha llevado a que algunos círculos académicos la descalifiquen en su totalidad. Su libro de 1999, sin embargo, está escrito de acuerdo con las normas básicas del trabajo académico y sus tesis, aunque discutibles, se apoyan en el debido aparato crítico. Su afirmación de que la insurrección de octubre «constituye, literal y rigurosamente, el comienzo de la guerra civil española», que por tanto habría sido iniciada por fuerzas de izquierda, parece responder a un propósito de debate ideológico más que a un análisis estrictamente histórico, pero en todo caso queda fuera del marco de análisis de este artículo, que no aborda las consecuencias de la insurrección. Así es que retendremos sólo su tesis de que la revuelta no buscaba "defender la república, sino asestarle el golpe de muerte» y que el PSOE la inició porque «creyó maduras las condiciones históricas para derrocar a la burguesía y realizar la revolución socialista»³.

\section{Una insurrección motivada por el malestar de los trabajadores}

La tesis de que los orígenes de la insurrección hay que buscarlos en el descontento de los trabajadores, más que en las decisiones de los dirigentes socialistas, ha sido expuesta por Adrian Shubert en su estudio sobre el movimiento obrero asturiano. Según Shubert, las intenciones de los líderes socialistas resultan ambiguas, porque el partido estaba dividido en tres corrientes, porque el ala caballerista hablaba de revolución de manera imprecisa, y porque el programa que habían aceptado, formulado por Prieto, tenía un contenido «democrático liberal» (curiosa afirmación que discutiremos más adelante). Así es que el impulso revolucionario vino más de los mineros asturianos que de sus líderes, por lo que los orígenes de la revolución han de buscarse en la crisis de la minería asturiana que se inició en los años veinte. La República dio una nueva esperanza, pero cuando se vio que no resolvía los problemas de los mineros, el sindicato socialista empezó a perder el control. La victoria de la derecha en las elecciones de 1933 y la siguiente represión acabaron con la ilusión republicana y empujaron a los mineros a la radicalización. Así es que los planes de los dirigentes socialistas proporcionaron el marco de la insurrección, pero no la causaron, se limitaron a «aplicar la cerilla al polvorín de malestar y rebeldía que había estado gestándose entre los mineros asturianos durante muchos años» ${ }^{4}$.

\section{Una insurrección para la conquista del poder motivada por una pluralidad} de factores

En contraste con las interpretaciones hasta ahora mencionadas, que subrayan un factor determinado (el temor a la reacción, la voluntad revolucionaria del PSOE

3 MOA, P., 1999: 9-11-

4 SHUBERT, A., 1984: 13-15 y 212-214. 
o el malestar de los trabajadores), hay otras más proclives a destacar la incidencia de varios factores. Es el caso de un artículo publicado por Marta Bizcarrondo en 1984, en el que sostuvo que desde diciembre de 1933 el PSOE decidió preparar una insurrección armada para la conquista del poder y que el problema estriba en entender los factores que les condujeron a esa decisión. Según ella, habrían sido cuatro: la crisis de la colaboración socialista con los gobiernos republicanos, la incidencia de la crisis económica en algunos sectores laborales, el ascenso de los fascismos en Europa y la influencia del modelo soviético. De todos ellos el primero habría sido el más importante: «el papel central corresponde a la frustración derivada de la experiencia de la colaboración gubernamental en el primer bienio republicano». La frustración vino de la perspectiva de que una política derechista pudiera anular las reformas conseguidas por los ministros socialistas, del sentimiento de que la democracia era una forma de gobierno que sólo beneficiaba a la burguesía, y de «la incapacidad de los socialistas españoles para pensar en términos de estrategia política su propio reformismo". Esto último significa que los socialistas se sentían incómodos al colaborar en el gobierno con partidos «burgueses». Toda la tradición del socialismo español conjugaba la práctica reformista con «una fe intransigente en los principios» y una colaboración gubernamental encaminada a impulsar una política de reforma social chocaba con esos principios revolucionarios nunca cuestionados ${ }^{5}$.

\section{Una insurrección para la conquista del poder enraizada en la cultura política socialista}

En un artículo de 1984, Santos Juliá argumentó que el discurso ideológico y político que llevó a los socialistas a alzarse en armas en octubre de 1934 tenía sólidas raíces en su cultura política. Juliá no negaba la importancia que tuvieron factores como la crisis económica, el auge del fascismo, la reacción patronal, la mayor militancia de las bases o la pérdida de las expectativas depositadas en la República, pero centró su análisis en el concepto de revolución que tenían los socialistas españoles. Su concepción era que la República de 1931 era el resultado de una revolución, en la que ellos habían participado y de la que había surgido un gobierno revolucionario. Su participación en ese gobierno tenía como finalidad robustecer la organización obrera, mediante el control del mercado de trabajo, al que seguiría un control sindical de la industria que constituiría el pórtico de la socialización. Juliá no veía por tanto esa contradicción entre práctica reformista y principios revolucionarios que tan importante era en la interpretación de Bizcarrondo. Según él, los socialistas creían estar haciendo una política revolucionaria tras haber participado en una revolución. Pero la revolución a la que se habían sumado en 1930 no era todavía la revolución socialista.

${ }^{5}$ BIZCARRONDO, M., 1984. 
«La República, tal como se había creado el 14 de abril, no era ciertamente una meta final, pero sí una estación de tránsito. De allí sólo se podía salir para continuar el camino, nunca para volver atrás». En este último párrafo está a mi juicio la clave de la interpretación de Juliá: la República de abril representaba un primer paso revolucionario al que habría de seguir el paso definitivo de la revolución socialista, pero cualquier intento de volver atrás, es decir de anular la obra de los ministros socialistas, representaría una inaceptable traición de los republicanos. Así es que cuando en septiembre de 1933 se formó un gobierno exclusivamente republicano, se sintieron traicionados. A partir de ahí sólo cabía dar otro paso adelante, la conquista del poder, ya fuera por la vía electoral, como se intentó sin éxito, ya fuera por la vía insurreccional. Sin embargo, los socialistas sólo irían a la insurrección se era el enemigo el que rompía la legalidad, lo que equivalía a dejar la iniciativa al gobierno. Cuando en octubre de 1934 Lerroux dio entrada en el gobierno a la CEDA, los socialistas concluyeron que la legalidad republicana se había violado y obraron en consecuencia 6 .

Por otra parte Juliá había destacado en un artículo anterior que los socialistas siempre habían concebido que su papel en una revolución debía ser fundamentalmente el de preparar una huelga general, como había ocurrido en 1917 y en 1930, y que el éxito requería del apoyo de un sector de las fuerzas armadas, y ese fue de nuevo el esquema al que se ajustaron en 1934, aunque esta vez con un mayor énfasis en el papel de sus milicias ${ }^{7}$.

Se debe añadir que la tesis de que la retórica revolucionaria de los socialistas, desde las elecciones de 1933 hasta la insurrección de octubre de 1934, respondía a un genuino proyecto revolucionario ha sido también defendida por Sandra Souto en su documentado estudio sobre el socialismo madrileño del período ${ }^{8}$.

\section{Una insurrección antidemocrática para rescatar a la República}

Este fue el singular modo en que José Manuel Macarro planteó la cuestión que en un artículo de 1985: la insurrección representó obviamente «una quiebra de la democracia», pero una interpretación basada en este hecho implica el error de creer que en la España de los años treinta los conceptos de democracia y República eran sinónimos. En 1933, recordaba Macarro, el $63 \%$ de los ciudadanos votaron a partidos que habían defendido de manera explícita un giro a la derecha respecto a la política del primer bienio. Pero las izquierdas no aceptaron esos resultados porque para ellos el contenido de la República no se agotaba en la democracia: «la República tenía que ser democrática, pero como medio de alcanzar unas metas de cambio en España». Así es que cuando los resultados electorales amenazaron la

\footnotetext{
${ }^{6}$ JULIÁ, S., 1985. Sobre las milicias socialistas véase GIBAJA VELÁZQUEZ, J. C., 1994

JULIÁ, S., 1984.

8 SOUTO, S., 2004.
} 
laicidad del Estado, las reformas militares y las sociales, las izquierdas emprendieron el camino de Octubre, que no fue «un asalto a la democracia, sino un intento de rescatar la República». Por otra parte, Macarro rechazaba la interpretación según la cual el triunfo electoral de las derechas había provocado «el hundimiento general de las condiciones de vida de los trabajadores" ${ }^{\text {. }}$

Sobre el tema de la concepción no exclusivamente democrática que las izquierdas tenían de la República, Macarro ha publicado otro artículo en 2001 en el que llega a la conclusión de que en 1934 «nadie en el mundo de la izquierda estaba hablando de democracia», se hablaba de «recuperar el hecho fundacional republicano», amenazado por la dirección «democráticamente ganada» de aquellos a quienes percibían como "enemigos del pueblo» "10. Una descripción que se ajusta muy bien a la actitud de Azaña y de la izquierda republicana, según he argumentado en otro lugar ${ }^{11}$, pero que choca con la interpretación según la cual en 1934 los socialistas no se planteaban defender la República del 14 de abril, sino entrar en una nueva etapa revolucionaria.

\section{REALIDAD Y PERCEPCIÓN: UN ENFOQUE DE TEORÍA DEL ENCUADRAMIENTO}

El propósito de este artículo es analizar una decisión, la de alzarse en armas, a la luz de los argumentos que sus protagonistas pudieron tomar en consideración, desde la amenaza que representaba la CEDA hasta las posibilidades de éxito. Podemos examinar hasta qué punto esos argumentos estaban basados en indicios reales y podemos también ver hasta qué punto eran coherentes con los principios ideológicos que los socialistas españoles venían defendiendo desde su fundación. Pero existe un tercer enfoque, complementario de los anteriores, que consiste en analizar como interactuaban el análisis de la realidad y la aplicación de los principios, tomando como base el enfoque que ofrece la teoría del encuadramiento (framing theory), un tipo de análisis cada vez más común en distintas ramas de las ciencias sociales.

El llamado efecto de encuadramiento (framing effect), a menudo observado por los estudiosos de la opinión pública, consiste en que una pequeña diferencia en el modo en que se presenta una cuestión o un hecho altera significativamente la percepción de ese hecho. Así es que se denomina encuadramiento al proceso mediante el cual la gente se forma una concepción de un asunto o reorienta su manera de pensar respecto a él. La mayoría de los estudios de teoría de la comunicación sobre encuadramiento asumen que los comunicadores son actores de elite, como políticos, periodistas, expertos y otros forjadores de opinión, mien-

\footnotetext{
9 MACARRO, J. M., 1985.

10 MACARRO, J. M., 2001.

11 AVILÉS FARRÉ, J., 2006: 241-252.
} 
tras que el público en general constituye la audiencia. Pero la comunicación no es siempre tan unidireccional, porque quienes eligen los encuadres (frames) lo hacen teniendo presente la audiencia a la que se dirigen, así es que las preferencias del público inciden a su vez en las posiciones adoptadas por la elite. Se da el caso curioso de que en los estudios sobre opinión pública se enfatizan los aspectos negativos del encuadramiento, tales como el carácter arbitrario de las preferencias populares y la capacidad de las elites para manipularlas, mientras que en los estudios sobre movimientos sociales se enfatizan sus aspectos positivos, al asumir que los individuos pueden afrontar sus problemas mediante la elaboración de encuadres compartidos, que facilitan la toma de decisiones colectivas ${ }^{12}$.

La importancia de este enfoque para la teoría de los movimientos sociales es que conduce a que estos movimientos no sean considerados meros portadores de ideas y significados que se desarrollan automáticamente a partir de la realidad social, los sucesos imprevistos o las ideologías existentes, sino que sus miembros sean percibidos como actores comprometidos activamente en la producción y el mantenimiento de significados, en competencia como otros actores. De esa actividad emergen encuadres de acción colectiva (collective action frames) que ofrecen una interpretación de la realidad, mediante un proceso de simplificación y de condensación de determinados aspectos de la misma, que les permiten movilizar a potenciales partidarios, ganar el apoyo de los no participantes y desmovilizar a sus antagonistas ${ }^{13}$.

Mediante este enfoque pretendemos profundizar en la línea iniciada en algunos de los estudios antes mencionados, para comprender como la fatídica decisión socialista de alzarse en armas contra las instituciones republicanas fue el resultado de un proceso activo de interpretación de la realidad (nadie está obligado a denominarlo encuadramiento si el término no le gusta) en el que incidieron los planteamientos tradicionales del socialismo español, los acontecimientos que se sucedieron en España a partir de 1931 y el ejemplo de lo que ocurría en otros países europeos. En concreto prestaremos atención a cinco cuestiones: la influencia de la doctrina marxista, la impronta de las prácticas políticas tradicionales en España, el modelo ruso de revolución, la experiencia del hundimiento de la democracia en Alemania y Austria, y el optimismo revolucionario derivado de una infravaloración de las fuerzas del enemigo. Todo ello lo analizaremos desde el punto de vista de la elite del movimiento, esto es de los dirigentes socialistas, muy especialmente Largo Caballero, y su órgano de prensa, pero sin olvidar que su mensaje de encuadramiento (de interpretación de la realidad, si se prefiere este término) estaba condicionado por la percepción que esta elite socialista tenía acerca de la actitud de sus propios seguidores, tema que merecería un estudio en profundidad, pero que aquí sólo se analizará brevemente.

12 CHONG, D. y DRUCKMAN, J. N., 2007.

13 BENFORD, R. D. y SNOW, D. A., 2000. 


\section{Radicalización de los dirigentes y radicalización de las bases}

¿Hasta qué punto respondió el mensaje radicalizado de los dirigentes del PSOE a las aspiraciones de sus seguidores? Años después, ya en el exilio, Fernando de los Ríos comentaría en una carta privada que a su partido le habían desorientado «la inundación de sus cuadros y la rebeldía de sus Juventudes» ${ }^{14}$. Es decir, que el PSOE habría perdido el rumbo por la deriva bolchevique de sus jóvenes y por la entrada masiva, en los momentos iniciales de la República, de unos nuevos militantes que no estaban acostumbrados a la tenaz y paciente lucha que las organizaciones socialistas habían llevado durante décadas y que por tanto se habían dejado llevar por la impaciencia revolucionaria. Lo que equivale a decir que las decisiones de la dirección socialista habrían sido resultado de la presión de sus militantes de base. El propio presidente de la UGT, Julián Besteiro, cuya oposición a la vía insurreccional le llevó a dimitir poco después, reconoció en diciembre de 1933,en una reunión conjunta de las comisiones del partido y el sindicato, que los trabajadores sentían más simpatía hacia «las locuras», como las promovidas por la CNT, que hacia la táctica que habían seguido las organizaciones socialistas, pero lo atribuyó en parte a que el discurso del propio partido estaba cambiando: en El Socialista se publicaban artículos de tipo bolchevique ${ }^{15}$. $Y$ en otra reunión celebrada en julio de 1934, fue Largo Caballero quien argumentó que, si ellos proponían un nuevo acuerdo con los republicanos de izquierda para ir a un movimiento conjunto, como pretendían Ríos y Prieto, los trabajadores les darían la espalda ${ }^{16}$.

Así es que parece haberse producido una radicalización simultánea de los dirigentes y las bases socialistas, pero es necesario investigar más a fondo los motivos de la radicalización de las bases. En todo caso no parece que fuera el resultados de un deterioro en las condiciones de los trabajadores a partir de la salida del gobierno de los socialistas. La política de los gobiernos que se sucedieron desde finales de 1933 tendía a reducir la capacidad de presión de los sindicatos socialistas, pero ello no se tradujo en un descenso general de los niveles salariales, según se ha comprobado en distintas investigaciones de ámbito local ${ }^{17}$. El ambiente prerrevolucionario parece pues haber surgido de factores más políticos que económicos. Probablemente resultaran decisivas las expectativas de una rápida transformación de las condiciones de vida que generó la proclamación de la República y que condujo a una masiva afluencia de militantes a las filas socialistas. En ese clima de entusiasmo, la toma del poder por el PSOE resultaba más atractiva que el lento proceso de transformación, punteado de retrocesos si el adversario ganaba las elecciones, que implicaba el sistema democrático.

14 F. de los Ríos a G. Ganga, 7-9-1942, citado en RUIZ-MANJÓN, O., 2007: 467.

15 Acta de la reunión conjunta de las ejecutivas del PSOE y la UGT, 11-12-1933, citada en LARGO CABALLERO, F., 1985: 30-35. El acta original no se conserva en los fondos de la FPI.

16 FPI, AFLC-19-23, acta de la reunión conjunta de las ejecutivas del PSOE y la UGT, 2-7-1934. Citada en LARGO CABALLERO, F., 1985: 112.

17 MACARRO VERA, J.M., 1985: 271-274. 


\section{La concepción marxista de la «democracia burguesa»}

La visión socialista de la República venía condicionada por un poderoso encuadre, siempre mantenido y realimentado, que consistía en esos principios revolucionarios a los que aludía Bizcarrondo, que conducían a que, en palabras de Juliá, la República fuera una estación de tránsito de la que sólo se podía partir hacia el socialismo. Estos principios eran los de la doctrina marxista, de acuerdo con la cual el tránsito desde una «República burguesa» como la española de 1931 hasta el socialismo, exigía una etapa de dictadura proletaria, a la que no se llegaría sin violencia. Esta tesis clásica, nunca abandonada en las etapas en que la práctica de las organizaciones socialistas era estrictamente reformista y respetuosa del marco legal, fue defendida en público por Largo Caballero en varias ocasiones durante el período que precedió a la insurrección.

Era todavía ministro de Trabajo cuando en julio de 1933, en un famoso mitin celebrado en el cine Pardiñas de Madrid, observó que lo más valioso de la experiencia republicana, mucho más que las leyes sociales, era que había llevado a la clase obrera a avanzar en el convencimiento de que una República burguesa no era suficiente para su emancipación ${ }^{18}$. Un mes después repitió la misma idea en una escuela socialista de verano: «realizar una obra socialista dentro de una democracia burguesa es imposible ${ }^{19}$. La democracia burguesa no era más que una mentira, afirmó meses después en un mitin electoral en Don Benito ${ }^{20}$. Era un sistema de opresión y violencia en la que el Estado tenía a su servicio, para oprimir al proletariado, a la fuerza pública, al ejército, a la magistratura, a la banca y a la prensa, según había explicado en una entrevista ${ }^{21}$.

Otro elemento básico del encuadre marxista era el determinismo histórico. De acuerdo con la concepción determinista propia del marxismo, los socialistas no concebían su triunfo revolucionario como una posibilidad, sino como una necesidad histórica ${ }^{22}$. Según un comentario editorial que El Socialista, dirigido por Julián Zugazagoitia, publicó en septiembre de 1933: «el proceso histórico exige, impone la revolución „23. Y ese mismo proceso histórico exigía que la revolución se realizara a través de la dictadura del proletariado, según explicó Caballero en la escuela de verano de agosto de 1933: «Entre la sociedad capitalista y la comunista hay un período de transición revolucionaria (...) y el Estado durante ese período no puede ser otra cosa que la dictadura del proletariado ${ }^{24}$. La violencia era también inevitable,

18 El Socialista, 25-7-1933.

19 El Socialista, 13-8-1933.

20 El Socialista, 10-11-1933.

21 El Socialista, 24-9-1933.

22 Acerca del determinismo histórico y la concepción revolucionaria de Marx resultan esclarecedores los análisis críticos de Karl Popper (1945) y Leszek Kolakowski (1976), que pueden consultarse en traducción española: POPPER, K., 1992 y KOLAKOWSKI, L., 1980.

23 El Socialista, 30-9-1933.

24 El Socialista, 13-8-1933. 
como explicó Caballero poco después en una entrevista con el entonces joven socialista Santiago Carrillo: «El capitalismo acudirá a la violencia máxima para mantener sus posiciones, y el socialismo tendrá que llegar también a la violencia máxima para desplazarle» ${ }^{25}$. Una perspectiva violenta que en los meses siguientes defendería con energía El Socialista. Cuando en enero de 1934, celebradas ya las elecciones, el diario católico El Debate llamó a la concordia, El Socialista le replicó en estos términos: «¿Concordia? ¡No! ¡Guerra de clases! ¡Odio a muerte a la burguesía criminal!»26.

\section{La tradición española: corrupción electoral y práctica insurreccional}

Pero no era sólo la doctrina marxista la que empujaba a los socialistas hacia la insurrección. En las primeras décadas del siglo XX todos los partidos socialistas europeos compartían en lo fundamental la doctrina marxista, pero la mayoría de ellos nunca optó por la vía insurreccional. Esta opción se hallaba en cambio muy arraigada en la cultura política española, debido a una experiencia histórica que se remontaba a comienzos del siglo XIX. En España el cambio político no se producía por el voto de los ciudadanos, sino mediante el empleo o la amenaza de la fuerza. Es bien sabido que en tiempos de la monarquía el sistema parlamentario se basaba en el falseamiento sistemático de las elecciones: el partido que las convocaba siempre las ganaba, por lo que la alternancia en el poder de los partidos conservador y liberal dependía de que el rey encargara alternativamente formar gobierno a uno y otro partido.

Lo llamativo es que el sistema democrático de la Segunda República siguiera siendo percibido por los socialistas a través de un encuadre basado en las pasadas experiencias de corrupción electoral. Las primeras elecciones parlamentarias en que el libre voto de los ciudadanos determinó un cambio fueron precisamente las de 1933, pero los socialistas malinterpretaron lo ocurrido como una continuación de las viejas pautas: a ellos les habían desalojado del gobierno, el presidente de la República se lo había otorgado al Partido Radical y éste había presidido unas elecciones en las que la izquierda había sido derrotada. En la primera vuelta de las elecciones las izquierdas sólo obtuvieron el apoyo del $36 \%$ de los electores, y si descontamos el $13,5 \%$ que correspondió a los partidos republicanos de izquierda, con los que los socialistas descartaron una nueva coalición, el porcentaje de votantes que apoyaron al PSOE y a sus potenciales aliados del minoritario PCE se reducía al 22,5. Por otra parte, no hay indicios de que prácticas corruptas influyeran significativamente en el resultado electoral; el propio ministro de Gobernación resultó derrotado. Así es que sólo un encuadre marxista, que atribuía al partido de la clase obrera la misión de guiar la marcha de la historia, puede explicar que el

25 El Socialista, 24-9-1933.

26 El Socialista, 3-1-1934. 
apoyo de tan sólo una quinta parte de la población bastara para plantearse la conquista del poder ${ }^{27}$.

Los cálculos de los propios dirigentes socialistas fueron muy similares, pues estimaron que por sí solos habían obtenido casi el $20 \%$ de los votos emitidos, pero su opinión fue que las elecciones no habían sido limpias: «se pusieron en práctica todos los usos y costumbres de corrupción, inmoralidad, coacciones y atropellos "28. Pero la concepción que los socialistas españoles de entonces tenían de la limpieza electoral era un tanto particular, según se desprende de un artículo que, tras conocerse los resultados de la primera vuelta, publicó el influyente intelectual socialista Luis Araquistain. En su opinión aquellos resultados se debían a una triple coacción: la coacción política del gobierno, la coacción moral de la Iglesia y la coacción económica de los propietarios territoriales, mientras que las elecciones de 1931 habían sido libres precisamente porque las fuerzas de derecha se hallaban acobardadas: «En 1931 las oligarquías y sus organismo caciquiles locales, acobardadas por la instauración de la República y por algunos actos de violencia popular como la quema de conventos, dejaron que el pueblo votara a su antojo en las elecciones de junio, las más libres de la historia de España ${ }^{29}$.

De estas palabras cabía deducir, aparte de la conveniencia de quemar conventos para evitar que la Iglesia coaccionara moralmente a los electores, que sólo la presencia de la izquierda en el poder garantizaba la libre expresión de la voluntad popular. Los socialistas dieron por ello una enorme importancia a su salida del poder, a partir de la cual estimaron que se había iniciado un nuevo período revolucionario. Así se decía en las instrucciones que la dirección socialista envió a los comités revolucionarios locales antes de la insurrección de octubre: «estamos viviendo un período revolucionario, el cual quedó abierto en el instante mismo en que se decretó la disolución de las Cortes Constituyentes» ${ }^{30}$. Largo Caballero lo había advertido cuando era todavía ministro en su discurso del cine Pardiñas: ellos podían optar por retirarse del gobierno, pero no admitían que se les expulsara del poder; su objetivo era conquistarlo y, si no les permitían hacerlo con arreglo a la Constitución y las leyes, tendrían que conquistarlo de otra manera ${ }^{31}$. Un gobierno de coalición entre los republicanos de distintas tendencias, sin participación socialista, como lo sería el efímero gobierno Lerroux de septiembre de 1933, representaba un retroceso respecto a la coalición republicano-socialista que venía gobernando desde el 14 de abril y era por tanto inaceptable. Así es que en julio, cuando esta eventualidad se veía venir, Largo Caballero anunció el camino que iban a seguir: la conquista del poder (se entendía que por sí solos, no en coalición

27 Véase un análisis de los resultados electorales en AVILÉS FARRÉ, J., 2006: 300-305

28 Fundación Pablo Iglesias, Alcalá de Henares (FPI), AH 24-6, memoria de la Comisión ejecutiva al Comité nacional del PSOE, 29-8-1934: 11.

29 El Socialista, 25-11-1933.

30 Conocemos estas instrucciones porque el propio Largo Caballero las copió en unas notas que se conservan en la Fundación Pablo Iglesias y han sido publicadas: LARGO CABALLERO, F., $1985: 105$.

31 El Socialista, 25-7-1933. 
con los republicanos), por las vías legales (las elecciones) y si esto no se les permitía, por otras vías (la insurrección).

A este respecto es importante recordar el recurso a la fuerza había sido a menudo utilizado con éxito en el pasado: la revolución de septiembre había destronado a Isabel II en 1868, el pronunciamiento de Martínez Campos había restaurado la monarquía en 1874 y el de Primo de Rivera había puesto fin al sistema liberal en 1923. Cierto es que la República se había implantado en abril de 1931 gracias al masivo voto republicano en unas elecciones municipales, pero el propósito inicial había sido imponerla mediante una insurrección, abortada en diciembre de 1930, en la que los socialistas se habían comprometido con los republicanos, así es que se podía interpretar el triunfo electoral de abril de 1931 como resultado de un proyecto revolucionario. Al sentirse traicionados por los republicanos tras haber perdido la participación en el gobierno, los socialistas se plantearon casi inmediatamente reanudar esa tradición. Apenas formado el gobierno de concentración republicana presidido por Lerroux, se produjo el 19 de septiembre una crucial reunión del Comité nacional del PSOE, en la que se discutió, en palabras de Largo Caballero, «si era conveniente que el Partido Socialista pudiera tener armas e implantar la República social, sin ayuda de nadie», algo que él mismo no veía posible por el momento. Quien más se opuso a esa posibilidad fue Indalecio Prieto, estaba como redactor del dictamen acerca de la declaración que había de hacerse pública, había omitido toda referencia a la conquista del poder, pero quedó en minoría. Por catorce votos contra tres, el comité acordó modificar el texto de Prieto para proclamar la resuelta decisión del partido «de defender a la República de toda agresión reaccionaria» y su convicción acerca de la necesidad «de conquistar el Poder político como medio indispensable para implantar el socialismo»32.

La fórmula era deliberadamente ambigua, pues aunaba un propósito de defensa de la República y otro de conquista del poder para implantar un régimen distinto. Los ejemplos europeos del momento resultaban relevantes en ambos sentidos: el caso alemán, al que pronto se sumaría el austriaco, podía ser utilizado como prueba de la necesidad de defender a la República de sus enemigos, mientras que el caso ruso estimulaba a quienes deseaban dar cuanto antes el paso hacia la República socialista. Veremos a continuación como influyeron en los socialistas españoles ambas experiencias.

\section{El modelo revolucionario ruso}

La importancia de la experiencia rusa para sus admiradores extranjeros residía en que demostraba la posibilidad real de realizar una revolución como la que Marx había predicho. Desde finales de 1918 el régimen soviético despertó un

32 FPI, AH-III-1, acta de la reunión del Comité nacional del PSOE, 19-9-1933: 93-97. 
gran entusiasmo entre los socialistas españoles y durante un tiempo el PSOE pareció mayoritariamente dispuesto a incorporarse a la Internacional Comunista. Las duras condiciones impuestas por esta condujeron sin embargo a que en 1921 un congreso del partido rechazara esa posibilidad, lo que dio origen a la escisión comunista. Durante los años veinte el interés por la experiencia soviética se redujo, para renacer tan sólo al final de la década ${ }^{33}$. En cambio, a lo largo de los años treinta, la admiración hacia la Rusia de Stalin alcanzó niveles elevadísimos, tanto en España como en otros países occidentales ${ }^{34}$. A partir de 1930 se produjo por primera vez una difusión masiva de libros y folletos marxistas en España y por primera vez surgió en las filas del PSOE un auténtico interés por la teoría marxista. En palabras de Marta Bizcarrondo, esta difusión del marxismo en la España de los años treinta se caracterizó porque se trataba de «un marxismo a la hora rusa» 35

Largo Caballero, el más influyente líder socialista del momento, no escatimó en su propaganda las referencias al modelo soviético. En su discurso en la escuela de verano de agosto de 1933, Largo Caballero hizo un elogio de los procedimientos revolucionarios rusos en política interior (por supuesto no iba a elogiar la política soviética en el exterior, que incluía la promoción de partidos comunistas subordinados a Moscú) y respecto a España observó que las circunstancias la iban conduciendo a una situación muy parecida (es decir hacia la revolución socialista) ${ }^{36}$. Un mes después explicó en una entrevista que le hizo Santiago Carrillo, por entonces miembro de las Juventudes Socialistas, que su partido y el comunista no se diferenciaban doctrinalmente en nada, porque ambos eran marxistas ${ }^{37}$. Según $E l$ Socialista, en Rusia se estaba realizando "un ensayo de dimensiones fantásticas», que los socialistas españoles apoyaban, aunque les separaran de los comunistas las condiciones que la Internacional Comunista exigía a los partidos miembros ${ }^{38}$. Y el ejemplo ruso fue también evocado por el líder socialista asturiano Amador Fernández, quien en enero de 1934 afirmó en un discurso que había que seguir el ejemplo de Lenin y tomar el poder para implantar el programa máximo socialista ${ }^{39}$.

\section{Los ejemplos alemán y austriaco}

En sentido contrario, los socialistas españoles quedaron impresionados por el hundimiento de la poderosa socialdemocracia alemana, que fue incapaz de oponerse al triunfo de Hitler. De ello fue testigo directo Luis Araquistain, embajador de

${ }^{33}$ Véase AVILÉS FARRÉ, J., 1999.

34 Véanse ELORZA, A. y BIZCARRONDO, M., 1999: 79-99; y CRUZ, R., 1999. BIZCARRONDO, M., 1986.

${ }^{35}$ BIZCARRONDO, M., 1986.

${ }^{36}$ El Socialista, 13-8-1933.

37 El Socialista, 24-9-1933.

38 El Socialista, 21-9-1934.

39 Avance, 28-1-1934, citado en SHUBERT, A., 1984: 194-195. 
España en Berlín desde abril de 1932 hasta doce meses después ${ }^{40}$. Pero, en un ejemplo destacado de lo importante que resulta el encuadre de un fenómeno, la lección que los socialistas españoles extrajeron no fue la de la necesidad de defender la democracia sino la de la inoperancia de esta frente a la amenaza fascista. Esa fue la tesis que Araquistain defendió en una conferencia pronunciada en la Casa del Pueblo de Madrid el 29 de octubre de 1933, en la que concluyó: «El dilema fatal es éste: franca dictadura burguesa o franca dictadura socialista» ${ }^{41}$. Dos meses antes, un comentario editorial de El Socialista ya había advertido que, en todo el mundo, los socialistas estaban perdiendo la fe en una democracia y en unas normas de convivencia social que daban por resultado el triunfo del fascis$\mathrm{mo}^{42}$.

Particular impresión causó en los socialistas españoles el fracaso de la insurrección que en febrero de 1934 lanzaron sus correligionarios austriacos contra la incipiente dictadura del canciller Dollfus. Con su insurrección, comentó El Socialista, los socialistas austriacos habían marcado el camino a seguir, pero ellos la habían iniciado tarde ${ }^{43}$. Aún así el fracaso de la insurrección era preferible a la derrota sin lucha sufrida en Alemania, como lo expresó gráficamente una viñeta en la que un obrero alemán, encerrado en un campo nazi, comentaba amargamente: «Los han vencido. ¡Quien pudiera decir lo mismo! »44. Por otra parte, el hecho de que Dollfus encabezara un partido católico hacía más fácil atribuir propósitos semejantes a la CEDA. "Son los correligionarios de Gil Robles - comentaba El Socialista en vísperas de la insurrección de octubre- los vaticanistas que mantienen sobre el pueblo austriaco el yugo feroz de la dictadura ${ }^{45}$. Los socialistas españoles se lanzaron a una insurrección frente a una amenaza autoritaria que no se había concretado en parte para evitar la suerte de sus camaradas austriacos que se habían lanzado a la insurrección cuando el régimen autoritario de Dollfus era ya una realidad.

\section{Optimismo revolucionario e imprevisión insurreccional}

Tomada la decisión insurreccional, los dirigentes socialistas trataron de preservar sus fuerzas para el enfrentamiento final, evitando que se malgastaran en conflictos parciales, aunque no pudieron impedir que la poderosa Federación de Trabajadores de la Tierra se lanzara a un huelga general en junio de 1934, sufriendo una derrota que hizo inviable la participación campesina en la insurrección de octubre ${ }^{46}$. Se lanzaron a ésta en respuesta a una decisión ajena, la entrada de

\footnotetext{
40 BIZCARRONDO, M., 1975: 121-134.

41 El Socialista, 31-10-1933.

42 El Socialista, 2-9-1933.

43 El Socialista, 16-2-1934.

44 El Socialista, 17-2-1934.

45 El Socialista, 4-10-1934.

46 MALEFAKIS, E., 1971: 386-393.
} 
la CEDA en el gobierno, sin pararse a considerar si disponían de fuerzas suficientes. Los historiadores han tendido pues a juzgar que se trató de movimiento sin posibilidad de triunfo. Santos Juliá, por ejemplo, ha escrito que una revolución «basada en una deplorable organización armada, sin objetivos políticos precisos, con la abstención de un numeroso sector de la clase obrera sindicalmente organizada, proyectada como mezcla de conspiración de militares presuntamente adictos y de huelga general del gran día, frente a un Estado que mantenía intacta su capacidad de respuesta, no tenía ninguna posibilidad de triunfar ${ }^{47}$.

Es difícil comprender qué percepción de la realidad condujo a los dirigentes socialistas a creer que podrían derrotar a las fuerzas del Estado. Largo Caballero parecía creer que el Ejército, integrado en buena parte por jóvenes de la clase obrera, no podría ser un instrumento efectivo frente a la revolución. Se refirió a ello en un discurso pronunciado en Murcia durante la campaña electoral de noviembre de 1933: «Hay quien cree que el fascismo puede venir ayudado por los militares. Pero estos militares no representan al ejército. El ejército, para nosotros, no son los generales, sino los proletarios que lo componen ${ }^{48}$. Consideraba por otra parte factible la creación de un ejército revolucionario, integrado por militantes socialistas, que fuera capaz de enfrentarse al ejército profesional. Así lo dijo en abril de 1934 en su intervención ante el congreso de la Federación de Jóvenes Socialistas: «Hay que crear un ejército revolucionario que poder enfrentar a nuestros enemigos. $\mathrm{Y}$ es preciso organizarlo militarmente, de manera que los hombres que compongan dicha organización hagan promesa de obediencia, porque de esta forma es como está organizado el ejército enemigo» 49 .

Las instrucciones para crear ese ejército revolucionario fueron reproducidas por el propio Largo Caballero en las notas que más tarde preparó para un libro. Se pretendía que en todas localidades posibles se formaran grupos de acción capaces de enfrentarse a las fuerzas del gobierno, que deberían hallarse en condiciones de lanzarse a la acción a las doce de la noche del día en que se diera la orden ${ }^{50}$. La organización del movimiento fue encomendada a una comisión mixta integrada por Juan-Simeón Vidarte y Enrique de Francisco, del Partido Socialista, Pascual Tomás y José Díaz Alor, de la UGT, y Carlos Hernández Zancajo y Santiago Carrillo, de las Juventudes Socialistas ${ }^{51}$. Pero la organización de las milicias socialistas quedó bajo el control del propio Largo Caballero, presidente del PSOE y secretario general de la UGT, que según el testimonio del ugetista Amaro del Rosal, «llevaba personalmente esta tarea», apreciación en la que coincide Santiago Carrillo, quien añade que el presidente del PSOE se había reservado demasiadas funciones ${ }^{52}$.

47 JULIÁ, S., 1997: 218.

48 El Socialista, 15-11-1933.

49 El Socialista, 21-4-1934.

50 LARGO CABALLERO, F., 1985: 93-102. En la FPI no se conservan los originales de estas instrucciones.

51 LARGO CABALLERO, F., 1985: 85-86.

52 ROSAL, A., 1983: 207-208. CARRILLO, S., 1993: 100 y 107. 
Parece sin embargo que las Juventudes Socialistas actuaron en alguna provincia un tanto al margen de las directrices centrales y asumieron la formación de las milicias sin contar con el PSOE ni la UGT. Esto es lo que se desprende de un interesante documento que se conserva en el archivo de Salamanca. Se trata de unas instrucciones enviadas en junio de 1934 por la Federación Provincial de Juventudes Socialistas de Murcia a todas sus secciones: «Toda milicia de las Juventudes Federadas de la provincia, estará integrada por individuos pertenecientes a nuestras colectividades juveniles, al Partido Socialista y a la U.G.T., concediendo limitaciones para los dos últimas clases de milicianos, y sólo será afectados por juicios favorables del Jefe local ${ }^{53}$ ». La redacción es un tanto abstrusa, pero el significado de la frase está claro: sólo el jefe local de las Juventudes Socialistas podía autorizar la incorporación a las milicias de militantes del PSOE y de la UGT. Resulta obvio que los jóvenes socialistas confiaban poco en sus mayores.

En definitiva, los preparativos fueron del todo insuficientes para la magnitud de la empresa que se preparaba. Se adquirieron algunas armas, tarea en la que destacó Indalecio Prieto, pero varios depósitos fueron descubiertos por la policía, uno de ellos en la Casa del Pueblo de Madrid, y el principal alijo, el que el buque Turquesa pretendía desembarcar en Asturias, no llegó a su destino al ser interceptada la operación por la Guardia Civil ${ }^{54}$. Hubo también contactos con elementos del Ejército, la Guardia Civil y la Guardia de Asalto, pero con escaso resultado ${ }^{55}$. En tales circunstancias resulta incluso dudoso que los socialistas desearan en octubre de 1934 lanzarse a la revolución que llevaban meses preparando. Según las notas que unos años después redactó Largo Caballero, habrían preferido que no se produjera esa entrada de la CEDA en el gobierno que ellos habían identificado como la provocación a la que habrían de responder con las armas: «El deseo de todos era que el presidente de la República procediera con buen sentido y no facilitara la entrada de la CEDA; pero, sin duda, deseaba la tragedia, pues él conocía (...) la actitud de la clase obrera» ${ }^{56}$.

¿Hemos de creer que los discursos revolucionarios, la formación de milicias y el acopio de armas habían tenido por principal objetivo amedrentar al presidente? Es posible que cuando redactó esas notas, Largo Caballero pretendiera eludir su propia responsabilidad y traspasársela a Alcalá-Zamora, pero esto no excluye que en octubre de 1934 hubiera realmente preferido posponer el momento de la insurrección, tal como apuntan en sus respectivas memorias dos de los participantes en la comisión que coordinó los preparativos revolucionarios, Juan-Simeón Vidarte y Santiago Carrillo, quienes coinciden en afirmar que el dirigente socialista confiaba en que Alcalá-Zamora evitaría la entrada de la CEDA en el gobierno ${ }^{57}$.

53 Archivo General de la Guerra Civil, Salamanca (AGGC), circular de la Federación Provincial de Juventudes Socialistas, Murcia, 6-6-1934.

54 LARGO CABALLERO, F., 1985: 143-149. ROSAL, A., 1983: 233-249.

55 ROSAL, A., 1983: 212-229.

56 LARGO CABALLERO, F., 1985: 150.

57 VIDARTE, J.-S., 1978: 231. CARRILLO, S., 1993: 97. 
Aunnque los preparativos revolucionarios iban en serio, a la hora de la verdad muchos de los implicados, incluido Largo Caballero, hubieran preferido no tener que dar en ese momento el paso crucial que ellos mismos habían acordado.

\section{INTERMEDIO: LA AMENAZA DE LA CEDA}

Antes de seguir adelante, conviene reflexionar un momento acerca de la CEDA. ¿Representaba ésta una versión española del fascismo, como parecían creer los socialistas? ¿Constituía más bien una nueva encarnación de la derecha tradicionalista? ¿Era una amenaza para esencia democrática de la República la reforma constitucional que exigía? Para responder a tales interrogantes lo mejor es analizar, aunque sea de forma somera, los discursos de su líder Gil Robles y los artículos de su órgano de prensa, El Debate ${ }^{58}$.

En primer lugar, hay que destacar que su actitud hacia el fascismo italiano resultaba ambigua, pues si bien rechazaban sus principios, aprobaban buena parte de su obra. En 1932, cuando se cumplían diez años de la marcha sobre Roma, El Debate hizo un balance del régimen de Mussolini en el que, junto a la crítica de la «divinización de la patria» y la "omnipotencia del Estado», rasgos fascistas que resultaban incompatibles con los principios católicos, elogiaba los «beneficios materiales» que había traído, los resultados de su «reacción antiliberal y antisocialista» $y$ el hecho de «haber libertado a Italia del parlamentarismo»59. Pero Gil Robles se mostró muy crítico con el fascismo en un discurso que pronunció unos meses después, en el que se opuso tanto a su doctrina como a su táctica: «Doctrinalmente, los movimientos fascistas son inadmisibles para quien afirme los postulados del Derecho público cristiano. Esas ideologías que de un modo genérico se conocen con el nombre de fascismo suponen la identificación de la nación y el Estado, la de éste con un solo partido político y anulan, en consecuencia, la personalidad individual ${ }^{60}$.»

En cuanto a la táctica, Gil Robles repudiaba el recurso del fascismo a la fuerza, porque podía parecer una manera muy fácil de resolver los problemas políticos, pero era peligrosa porque resultaba casi siempre imposible «mantener la violencia en los términos previstos" y evitar que se desbordaran las pasiones. Un rechazo al empleo de la violencia que planteó en términos más concretos en junio de 1933, al clausurar un ciclo de conferencias de las Juventudes de Acción Popular, que al igual que las Juventudes Socialistas se sentían atraídas por las actitudes más radicales: «Nosotros no podemos formar bandas de pistoleros (...) Enviar muchachos de dieciocho años a vengar muertes con muertes constituye un delito de lesa pa-

58 Para un análisis más amplio de las posiciones de la CEDA respecto a la democracia y el fascismo véase MONTERO, J. R.: II, 141-178.

59 El Debate, 28-10-1932.

60 Discurso en Barcelona, 21 de marzo de 1933, citado en GIL ROBLES, J. M., 1971: 216-217. 
tria. Vosotros, los jóvenes, debáis huir de la cobardía; pero nunca llegar al asesinato, aunque sea para defender nobles ideas ${ }^{61}$.»

Pero el rechazo a los medios violentos y a los principios doctrinales del fascismo no excluía la admiración hacia ciertos aspectos del régimen de Mussolini e incluso del de Hitler. Cuando este llegó al gobierno, en enero de 1933, El Debate afirmó que la nueva situación alemana tenía «facetas alarmantes», pero también «aspectos constructivos» y expresó su esperanza en que el partido católico alemán, el Centro, supiera «moderar el impulso belicoso de los nazis y al tiempo aprovechar lo que tenía "de beneficioso y de laudable» el proceso de reforma emprendido ${ }^{62}$. Su corresponsal en Berlín, Bermudez de Cañete, destacaba sobre todo en sus crónicas el entusiasmo que despertaba Hitler y su respeto a la religión, que en opinión de algunos hacía que los buenos católicos pudieran votarle «sin la menor intranquilidad de conciencia ${ }^{63}$. En cuanto al antisemitismo nazi, el cronista católico lo encontraba al menos explicable: «El pueblo alemán tiene profunda aversión a los judíos, lo que si no justificable, es explicable. Desde la guerra los judíos se han distinguido siempre por sus escándalos financieros, por su internacionalismo y por su protección al marxismo ${ }^{64}$.»

El propio Gil Robles mostró su admiración por los logros de Hitler tras un viaje a Alemania que realizó en el verano de 1933. En una entrevista publicada en el boletín de la CEDA explicó que en el nuevo régimen alemán había elementos inadmisibles, pero también muchos que resultaban aprovechables para la CEDA, a condición de amoldarlos a su temperamento y doctrina: «Su raíz y su actuación eminentemente populares; su exaltación de los valores patrios; su neta significación antimarxista; su enemiga a la democracia liberal y parlamentarista; su labor, coordinadora de todas las clases y energías sociales; su aliento juvenil, empapado de optimismo (...) Todo esto traza las directivas de un nuevo orden de cosas, que nosotros estamos en el deber de recoger, para armonizarlo con los postulados de la doctrina católica ${ }^{65}$

Al canciller austriaco Dollfus no era necesario armonizarlo, pues su régimen proclamaba una inspiración católica, así es que El Debate se mostró muy favorable al mismo ${ }^{66}$. Al igual que la derecha católica austriaca, la CEDA aspiraba a un régimen católico y autoritario, muy en línea con los planteamientos de la derecha tradicionalista. En un discurso pronunciado en Salamanca en diciembre de $1932 \mathrm{Gi}$ Robles llegó a decir que la única diferencia entre los tradicionalistas y la CEDA era que aquellos tenían diez principios fundamentales, mientras que ésta tenía nueve

61 Discurso en Madrid, 27-6-1933, citado en GIL ROBLES, J. M., 1971: 328.

62 El Debate, 31-1-1933.

${ }_{63}$ Sobre la actitud de El Debate respecto a la llegada de Hitler al poder véase SEMOLINOS, M., 1985: $152-156,225-226$ y 255-260.

64 El Debate, 10-3-1933.

65 C.E.D.A., n. ${ }^{\circ}$ 10, 30-9-1933, citado en MONTERO, J.R., 1977: 250-251.

66 Véase MONTERO, J.R., 1977: II, 254-256. 
fundamentales y uno accidental ${ }^{67}$. Es decir, que la CEDA era un partido tradicionalista excepto en que no consideraba fundamental la monarquía, sino que proclamaba la accidentalidad de las formas de gobierno, lo que le permitía acatar la República. Su primer objetivo era la reforma de la Constitución de 1931, no sólo para eliminar sus artículos anticlericales o socializantes, sino para reducir el papel del parlamento.

Gil Robles lo dijo muy claramente en el discurso con el que inició en Madrid la campaña electoral, en octubre de 1933: «Nuestra generación tiene encomendada una gran misión: tiene que crear un espíritu nuevo, fundar un nuevo Estado (...). Hay que buscar la unidad de espíritu, la verdadera unidad nacional; poner a España en armonía con las corrientes espirituales que renacen en el mundo; hacer un Estado fuerte que respete las libertades individuales, pero que realice e imponga con los intereses generales (...). Para realizar este ideal, no vamos a detenernos en formas arcaicas. La democracia no es para nosotros un fin, sino un medio para ir a la conquista de un Estado nuevo. Llegado el momento, el Parlamento se somete, o le hacemos desaparecer ${ }^{68}$.»

Estado nuevo, Estado Novo, era exactamente la expresión con que se designaba la dictadura portuguesa de Salazar, que en 1933 se dotó de una constitución en la que subsistían ciertas formalidades liberales, como la declaración de derechos, la separación de poderes y la existencia de una asamblea representativa, pero que tenía un contenido básico netamente autoritario ${ }^{69}$. No es demasiado aventurado suponer que un régimen semejante era el que deseaba la CEDA. En ulteriores discursos de la campaña electoral Gil Robles precisó los propósitos de ésta: no querían «un poder personal», pero tampoco «un parlamentarismo disolvente»; por ello pedían la revisión de la Constitución, no sólo en su parte dogmática, que repugnaba a su conciencia, sino en su parte orgánica, que primaba un parlamento que era «el elemento más activo de la disolución del pueblo español»; y para ello no iban a acudir a modelos extranjeros, «muy respetables», pero que acababan de surgir, sino a la tradición española. Iban a hacer «un ensayo, quizás el último, de la democracia», pero si el parlamento se oponía a sus ideales, irían en contra del parlamento ${ }^{70}$.

Tras los resultados electorales, que le dieron una sólida posición parlamentaria, Gil Robles se ofreció a apoyar a gobiernos republicanos de centro, posponiendo de momento su programa máximo de creación de un nuevo Estado. Así lo dijo en diciembre de 1933 en el debate parlamentario que siguió a la declaración ministerial del nuevo jefe de gobierno Alejandro Lerroux, un debate en el que una interrupción de José Antonio Primo de Rivera le llevó a marcar distancias respec-

\footnotetext{
67 El Debate, 27-12-1932.

68 Discurso de 15-10-1933, citado en GIL ROBLES, J.M., 1971: 269-270.

69 TORRE GÓMEZ, H., 1997: 26-28.

70 Discursos citados en ROBINSON, R. A. H., 1973: 225.
} 
to al fascismo. El líder de la CEDA había afirmado que la Constitución de 1931, ultraparlamentaria y ultrademocrática, no permitía gobernar y que en aquel momento, en el que en el mundo entero iba conquistando adeptos la corriente antidemocrática y antiparlamentaria, empeñarse en mantenerla sólo llevaría a una dictadura de izquierda o a una dictadura de derecha, que era la peor de las soluciones. Le interrumpió entonces Primo de Rivera, para decir que la buena solución era una dictadura, no de izquierda o de derecha, sino «integral, autoritaria», a lo que Gil Robles replicó que, con todos los respetos, él no podía aceptar un régimen basado «en un concepto panteísta de divinización del Estado y en la anulación de la personalidad individual», porque eran contrarios a sus principios religiosos ${ }^{71}$.

Meses después, en mayo de 1934, un debate en el que se enfrentó a los socialistas condujo a Gil Robles a hacer una declaración de explícita adhesión a la República: «Nosotros hemos proclamado con hechos que estamos sirviendo y defendiendo a la República, para salvar a España por medio de ella, sobre todo „ ${ }^{72}$. Estas palabras fueron ratificadas por el Consejo Nacional de la CEDA, convirtiéndose así en la doctrina oficial del partido ${ }^{73}$.

¿Qué cabe deducir de toda esta sucesión de declaraciones un tanto contradictorias? En primer lugar, que el ideal de la CEDA no era la democracia parlamentaria, sino algún tipo de régimen autoritario, más o menos similar a los de Dollfus en Austria y Salazar en Portugal. En segundo lugar, que no estaban dispuestos a utilizar para la conquista del poder la violencia en la calle, al estilo fascista. Y en tercer lugar, que tras los buenos resultados electorales de 1933 su lenguaje se fue suavizando y la denuncia de la democracia parlamentaria dio paso a un acatamiento formal de las instituciones republicanas.

\section{LOS OBJETIVOS DE LA INSURRECCIÓN}

Tras esta aclaración sobre los propósitos de la CEDA, podemos volver al tema central de este ensayo, los objetivos de los socialistas en octubre de 1934 ¿Qué pretendían lograr con la insurrección? ¿Querían salvar a la propia República, amenazada desde dentro? ¿Querían evitar el establecimiento de una dictadura fascista? ¿O más bien pretendían establecer un régimen socialista?

\section{Contra la República}

El examen de la documentación no deja lugar a dudas: la República tal como había quedado instituida en la Constitución de 1931 no tenía el menor atractivo

71 Discurso de 19-12-1933, citado en GIL ROBLES, J.M., 1971: 285-286.

72 Discurso de 2-5-1934, citado en GIL ROBLES, J.M., 1971: 318-319.

73 MONTERO; J. R., 1977: II, 77. 
para los socialistas, porque no era más que un régimen burgués. De ahí la decisión tomada en la mayoría de las circunscripciones de no formar coalición con los republicanos de izquierda en las elecciones de 1933, a pesar de que ello iba a dificultar sin duda la continuación de la política reformista iniciada en el primer bienio republicano. Puede que los socialistas confiaran en lograr ellos solos una mayoría parlamentaria que les permitiera conquistar el poder por la vía de la legalidad, pero es también posible que contaran con un resultado electoral que impidiera la formación de gobiernos estables y contribuyera con ello al declive de la República. Al menos esto es lo que dijo el propio Largo Caballero en un mitin electoral en la localidad de Zafra, en Extremadura, una región en la que los militantes socialistas eran particularmente hostiles a la colaboración con los republicanos. Sostuvo es que en la próxima legislatura, al negarse los socialistas a participar en el gobierno, sería imposible gobernar, lo que llevaría a una disolución anticipada de las Cortes, con lo que se abriría un nuevo período revolucionario, que ya no sería el de abril de 1931 y que habría de culminar «en el advenimiento de la República social» ${ }^{74}$. El cálculo parecía ser que ni Azaña, falto del apoyo socialista, ni tampoco Lerroux, contarían con la mayoría parlamentaria necesaria para gobernar. En cuanto a la legalidad republicana, tenía para Largo Caballero, lo mismo que para Gil Robles, un significado puramente instrumental, como explicó en otro mitin, este en Albacete: «Si la legalidad no nos sirve, si impide nuestro avance, daremos de lado la democracia burguesa e iremos a la conquista revolucionaria del poder ${ }^{75}$. Un editorial de El Socialista comentaba por entonces que no había «una docena de obreros dispuestos a salvar la República ${ }^{76}$.

Cuando en la primavera de 1934, ante la creciente influencia de las derechas, los republicanos de izquierda comenzaron a plantearse algún tipo de acción destinada a devolver a la República su orientación original y pensaron en una posible participación de los socialistas, éstos no se mostraron para nada favorables. El Socialista replicó que no se trataba de intentar otro 14 de abril, sino que era necesario «un octubre español», y que si tres años antes el movimiento se había hecho "con un papel», es decir la papeleta de voto, ahora se haría «con un fusil»" Pero el tema no fue discutido a fondo por la dirección socialista hasta comienzos de julio, cuando Prieto planteó en una reunión conjunta de las ejecutivas del partido y el sindicato que Azaña deseaba saber cual iba a ser la actitud socialista si, como se rumoreaba, el presidente de la República dimitía. En dicha reunión tanto Prieto como Fernando de los Ríos defendieron que se contara con los republicanos de izquierda para un movimiento del que surgiría un gobierno de mayoría socialista, pero su propuesta no obtuvo apoyo ${ }^{78}$. Los dirigentes socialistas aceptaron sin

74 El Socialista, 31-10-1933.

75 El Socialista, 14-11-1933.

76 El Socialista, 26-11-1933.

77 El Socialista, 29-4-1934.

78 FPI, AFLC-19-23, acta de la reunión conjunta de las ejecutivas del PSOE y la UGT, 2-7-1934. Reproducida en LARGO CABALLERO, F., 1985: 111-114. 
embargo reunirse con Azaña, que parecía dispuesto a promover una «acción común» para enderezar el rumbo de la República ${ }^{79}$. En dicha reunión, que tuvo lugar el 14 de julio, Largo Caballero le explicó, según Azaña, que los socialistas «habían acordado no colaborar con los republicanos ni para la paz ni para la guerra", porque iban a hacer solos la revolución, para implantar con un gobierno socialista un programa de «reformas audaces» (es decir el programa aprobado por las ejecutivas del partido y el sindicato en enero) ${ }^{80}$.

Esa reunión no se hizo pública, pero El Socialista dejó muy claro en aquellos días su rechazo total hacia la República del 14 de abril. Un día comentó que ésta se había deshonrado en las últimas elecciones por los pactos del gobierno con las derechas y que, a partir de ahí, no se precisaban más elecciones porque la República ya no merecía vivir ${ }^{81}$. En otra ocasión, llegó a decir: "Que se muera ${ }^{82}$. Y poco después insistió en estos términos: «¿A manos de quien debe morir? A las de cualquiera. Eso nos es indiferente. Lo que nos importa son las manos que hayan de facilitar nacimiento y vida del régimen futuro» ${ }^{83}$.

\section{Contra el fascismo}

La clave de la actitud socialista era su convicción de que no se podía volver a atrás: la República del 14 de abril había quedado superada por el inexorable avance de la historia y el dilema real se refería al régimen que habría de sucederle. Un año antes Largo Caballero había planteado ya, en el famoso discurso del Pardiñas, cuales eran los términos de ese dilema: frente a «la dictadura burguesa o el fascismo», ellos preferían "la dictadura socialista» ${ }^{84}$. Esa era la opción y en esos términos ha de entenderse la revolución de octubre, que fue un movimiento para impedir una dictadura como la austriaca, propósito que ellos atribuían a la CEDA, y para implantar otra, la del Partido Socialista. Los dirigentes socialistas, sin embargo, enfatizaron más el primer propósito que el segundo, no sólo por no crearse enemigos, sino porque habían optado por lanzar su insurrección como respuesta a una provocación previa de la derecha y si vieron una provocación en la entrada en el gobierno de tres ministros de la CEDA fue porque llevaban meses identificando en su propaganda al fascismo con la CEDA. No parece que se hubieran dado cuenta de que el genuino fascismo representaba un movimiento nuevo, que se diferenciaba de la derecha tradicional por su recurso a la movilización de masas, por su culto a la violencia y por su propósito de establecer un Estado totalitario. Para ellos fascismo, monarquía y catolicismo eran términos casi inter-

79 Acerca de la actitud de Azaña en estos meses véase AVILES FARRÉ, J., 2006: 344-356.

80 Carta de M. Azaña a C. Rivas Cherif, 23-7-1934, reproducida en RIVAS CHERIF, C., 1980: 647648. La versión del dirigente socialista se halla en LARGO CABALLERO, F., 1985: 114-115.

81 El Socialista, 20-7-1934.

82 El Socialista, 25-7-1934.

83 El Socialista, 28-7-1934.

84 El Socialista, 25-7-1933. 
cambiables, hasta el punto de que El Socialista llegó a afirmar que en España el fascismo era obra de la Compañía de Jesús ${ }^{85}$.

No hay que confundir, por otra parte, la lucha contra el fascismo con la defensa de la democracia, que los socialistas consideraban por entonces como algo superado con la experiencia de la República del 14 de abril. Esto quedó muy claro en el debate que se produjo en la reunión conjunta de las ejecutivas del PSOE y la UGT celebrada el 25 de noviembre de 1933, conocidos ya los resultados electorales. En ella Largo Caballero propuso un compromiso «para realizar un movimiento revolucionario a fin de impedir el establecimiento de un régimen fascista». Besteiro planteó entonces si se había previsto que ese movimiento, de llevarse a efecto, fuera "para defender la República y la democracia», y a ello Wenceslao Carrillo replicó que el acuerdo era no hablar «ni de una acción para implantar el socialismo, lo que habría de restarnos bastantes ayudas, ni de defensa de la democracia por si con ello se enfriaba el entusiasmo de nuestros camaradas». Largo Caballero también era partidario de la ambigüedad: la posición socialista debía ser la de impedir el triunfo del fascismo «y luego ya se vería cual era la conducta a seguir» ${ }^{86}$. Todo esto resulta muy esclarecedor: los militantes socialistas estaban dispuestos a batirse por implantar su propio régimen, no por defender la democracia republicana, pero a su vez la abierta proclamación de que se pretendía establecer un régimen socialista podría restar al movimiento posibles ayudas, por ejemplo en los sectores republicanos de las fuerzas armadas. Sólo Besteiro parece haber comprendido el error que en todo caso supondría un movimiento que supusiera una ruptura con la legalidad republicana. Lo dijo en otra reunión de las ejecutivas celebrada el 18 de diciembre: las derechas, «por sólo colocarse en actitud de respeto a la Constitución», tenían una posición firme, mientras que si ellos iban a un movimiento, incluso en alianza con otras fuerzas, les esperaba el fracaso ${ }^{87}$.

Como sabemos, un mes después, en enero de 1934, ambas ejecutivas aprobaron el proyecto insurreccional y Besteiro dimitió. Tras ello nadie en las filas socialistas se opuso a la nueva estrategia, que implicaba una ruptura con la democracia republicana. La provocación derechista, que habría de desencadenar el movimiento, era incluso deseada por algunos sectores. El Socialista lo dejó muy claro en un editorial publicado diez días antes de la insurrección, en el que descalificaba el proyecto de Azaña de un movimiento que permitiera devolver a la República su orientación original sin recurrir a las armas: «Renuncie todo el mundo a la revolución pacífica, que es una utopía. En período revolucionario no hay país que no esté en guerra. Bendita la guerra contra los causantes de la ruina de España. Si los republicanos que se preparan a tomar el poder, esto es la clase media y la pequeña burguesía, no se encuentran en condiciones de abatir al coloso feu-

\footnotetext{
85 El Socialista, 18-9-1934.

86 LARGO CABALLERO, F., 1985: 43-44.

87 LARGO CABALLERO, F., 1985: 60.
} 
dal, quédense en casa. Preferimos que se dé el poder a Gil Robles. Con los monárquicos nos batimos mejor sin intermediarios ${ }^{88}$.

El camino emprendido era el de la revolución social y para ello los republicanos sobraban. Podían aceptar en cambio la colaboración de las otras fuerzas revolucionarias, como los comunistas y los anarcosindicalistas, con los cuales los socialistas estaban dispuestos a constituir «alianzas obreras", aunque no a compartir la dirección del movimiento. Y para un acuerdo con la CNT estorbaba toda referencia a la República, como quedó claro en las negociaciones con la única federación regional cenetista que se sumó al movimiento, la de Asturias. Según el informe que un miembro de la comisión que negoció con la UGT envió al comité de la CNT asturiana, la propuesta inicial de los socialistas planteaba como objetivo de la alianza: «el triunfo de la Revolución social en España y llegar a la conquista del poder político y económico para la clase trabajadora, cuya concreción inmediata será la República Socialista Federal». Los cenetistas lograron sin embargo que se eliminara la palabra República y en el pacto que se firmó el 28 de marzo de 1934 el objetivo final quedó en el establecimiento de «un régimen de igualdad económica, política y social fundado sobre principios socialistas y federalistas». Pero en la versión del pacto que se hizo pública este objetivo final no se mencionó, para que las autoridades no advirtieran su carga revolucionaria, y se mencionó en cambio la lucha contra el fascismo, a la que nunca se había aludido durante las negociaciones que llevaron al pacto ${ }^{89}$. En el caso específico de Asturias, la única región de España donde hubo una auténtica insurrección, la lucha antifascista no fue pues sino una tapadera bajo la que se ocultaba su verdadero propósito. Algunos estudios, sin embargo, se han limitado a reproducir el texto del pacto que se hizo público, dando así una imagen distorsionada de los orígenes del movimiento ${ }^{90}$

\section{Por la dictadura socialista}

De lo anterior no debe deducirse, sin embargo, que los socialistas pretendieran implantar inmediatamente su programa máximo de socialización integral de la economía. Su objetivo básico era político, apoderarse definitivamente de los resortes del poder, y las medidas socializadoras se irían implantando a medida que las circunstancias lo permitieran. Lo había dicho ya Largo Caballero en julio de 1933 en su importantísimo discurso del cine Pardiñas: la conquista del poder serviría, por un lado, para «cambiar todos los instrumentos de Gobierno» y, por otro, para «cumplir el programa en la medida en que lo permitiese la situación económica, política y cultural del país» ${ }^{91}$. Cuáles eran esos instrumentos del poder que

88 El Socialista, 25-9-1934.

89 AGGCE, PS, Gijón, J 12/3, Informe de la Comisión de Alianza al Comité de la Confederación Regional del Trabajo de Asturias, León y Palencia, 10-4-1936.

90 Es el caso de SHUBERT, A., 1984: 203.

91 El Socialista, 25-7-1933. 
había que transformar lo dijo claramente unas semanas después en su discurso de la escuela de verano, se trataba de la burocracia, el ejército, la policía, los tribunales de justicia y la prensa ${ }^{92}$. De acuerdo con la concepción marxista, las instituciones del Estado nunca eran neutrales, sino que respondían a unos intereses de clase, burgueses en este caso, y un gobierno socialista sería impotente si no las transformaba para ponerlas al servicio del proletariado. En cuanto a la prensa de empresa, respondía de manera directa a los intereses burgueses, por lo que estaría siempre en contra del socialismo.

Esa transformación exigiría violencia y Largo Caballero no lo ocultó. En plena campaña electoral, en un discurso que pronunció en la localidad extremeña de Azuaga, explicó que el haber respetado tras el 14 de abril las vidas y haciendas de quienes hasta entonces les habían maltratado fue un error que no iban a repetir, y justificó en nombre de la historia la necesidad de cometer actos que en principio repugnaban, a fin de consolidar el nuevo régimen ${ }^{93}$.

¿Qué se proponían hacer los socialistas tras conquistar el poder? El programa revolucionario, redactado por Indalecio Prieto, que la ejecutiva del PSOE aprobó el 13 de enero de 1934 y la ejecutiva de la UGT aceptó dos semanas después, preveía algunas medidas muy radicales. Todas las tierras se declararían propiedad del Estado, que permitiría a los propietarios minifundistas seguir cultivándolas mediante el pago de un canon, mientras que en las áreas latifundistas se establecerían explotaciones colectivas, lo que implicaba, aunque no se mencionara expresamente, el recurso a la expropiación sin indemnización, posibilidad que el artículo 44 de la Constitución condicionaba a la aprobación de una ley en las Cortes por mayoría absoluta. Se reduciría el acceso a la enseñanza universitaria a aquellos alumnos que hubieran demostrado sus excepcionales condiciones en la escuela primaria, momento a partir del cual recibirían una educación especial. Serían disueltas todas las órdenes religiosas, medida que el artículo 26 de la Constitución sólo autorizaba en el caso de aquellas que representaran «un peligro para la seguridad del Estado». Todos los órganos del Estado serían modificados sustancialmente, el Ejército y la Guardia Civil serían disueltos, y el presidente de la República cesaría en sus funciones ${ }^{94}$.

La Constitución de 1931 no era mencionada en el programa revolucionario, pero se sobreentiende que sería abolida sin más, evitando los trámites previstos para su reforma en su artículo 125. Las medidas citadas no serían discutidas previamente por las Cortes, sino que serían implantadas por decreto y convalidadas posteriormente «por los órganos legislativos que libremente se diera el pueblo». Esta última referencia parecía sugerir una dictadura temporal, previa al establecimiento de una nueva república con un poder legislativo elegido por el

92 El Socialista, 13-8-1933.

93 El Socialista, 10-11-1933.

94 FPI, AH-II-1, acta de la comisión ejecutiva del PSOE, 12-1-1934. Reproducida en LARGO CABALLERO, F., 1985: 70-72. 
pueblo, pero la vaguedad de la formulación no permite asegurar que fuera a tratarse de un sistema democrático. Lo fundamental es que la disolución del Ejército y la Guardia Civil pondría la fuerza de las armas al servicio del nuevo régimen socialista. El Ejército sería reorganizado sobre la base de la reducción de sus contingentes y la separación de todos los generales, jefes y oficiales, «sin más excepción que las de aquellos que hubieran revelado sin tibieza su adhesión al régimen". En cuanto a las nuevas fuerzas de seguridad, tendrían como núcleo principal «unas milicias reclutadas exclusiva o preponderantemente entre los afiliados a las organizaciones que realizaran las transformaciones apuntadas en este programa ${ }^{95}$. Es decir que el control del orden público quedaría en manos de los milicianos socialistas y, si participaban en el movimiento, de los milicianos comunistas y anarcosindicalistas.

Sorprendentemente, algún historiador ha escrito que este programa tenía «un contenido democrático liberal» ${ }^{96}$, como si la reforma de las instituciones democráticas mediante la insurrección armada fuera un procedimiento democrático universalmente aceptado. De muy otra manera lo veía El Socialista, que en mayo de 1934 defendía «la dictadura revolucionaria del Partido Socialista con el proletariado que se disponga a emanciparse", es decir con las otras fuerzas obreras y revolucionarias que participaran en el movimiento ${ }^{97}$. En todo caso hay que recordar que el programa revolucionario no se dio a conocer previamente a la insurrección, así es que los objetivos precisos de ésta quedaron indefinidos. Carrillo, que formaba parte de la comisión de enlace revolucionaria integrada por los representantes del partido, el sindicato y las juventudes, ha afirmado en sus memorias que el programa no fue debatido en dicha comisión y que las juventudes no llegaron a conocerlo, probablemente porque Largo Caballero no le daba importancia alguna: lo necesario era tomar el poder y tras ello ya se vería qué podía hacerse. Así es que la comisión no llegó a debatir los objetivos políticos del movimiento, aunque sus miembros compartían la convicción de que el PSOE era el partido bolchevique de España e iba a implantar la dictadura del proletariado ${ }^{98}$. No hubo tampoco un manifiesto revolucionario previo a la insurrección porque, según el testimonio de Vidarte, Largo Caballero temía que sus firmantes se convirtieran en víctimas de la represión: era por tanto preferible que la insurrección apareciera como una protesta espontánea del pueblo ${ }^{99}$.

Las Juventudes Socialistas, por su parte, sí que tenían claros sus objetivos. La ponencia política que aprobaron en su V Congreso, celebrado en abril de 1934, afirmaba: «su firme creencia en los principios de la revolución proletaria y en que los momentos actuales no permiten otra salida que la insurrección armada de la

\footnotetext{
95 Ibidem.

96 Es el caso de SHUBERT, A., 1984: 14.

97 El Socialista, 24-5-1934.

98 CARRILLO, S., 1993: 96 y 105.

99 VIDARTE, J.-S., 1978: 221.
} 
clase trabajadora para adueñarse del Poder político íntegramente, instaurando la dictadura del proletariado» ${ }^{100}$.

\section{CONCLUSIÓN}

Los socialistas no se plantearon la insurrección de octubre como un movimiento destinado a defender a la República de una amenaza fascista. No había indicios de que la entrada de tres ministros de la CEDA en el gobierno fuera a conducir al establecimiento de la dictadura. El hundimiento de la democracia en varios países europeos, especialmente en Alemania y Austria, les había convencido sin embargo de que la democracia era un régimen inestable que fácilmente podía conducir a una dictadura fascista, convicción a la que les predisponía la doctrina marxista. A partir de la caída del gobierno de coalición republicano-socialista en septiembre de 1933 entendieron que había concluido la etapa democrática de la revolución española y se iniciaba la etapa socialista. Por otra parte, el escaso arraigo de la cultura democrática en España contribuyó a que negaran todo valor a los resultados electorales de noviembre de 1933. Y tanto el avance del fascismo como los aparentes éxitos de la Unión Soviética en los años en que Stalin forzó la colectivización total y puso en marcha los planes quinquenales, contribuyeron a que entendieran que el dilema del momento se planteaba entre dictadura burguesa, de carácter fascista, y dictadura socialista, basada ésta en el modelo soviético. El choque violento entre ambas opciones parecía inevitable y los socialistas decidieron ser los primeros en pasar a la acción, aunque esto implicara una sobrevaloración de las fuerzas con las que contaban para lanzar su desafío al Estado.

En la decisión insurreccional influyeron por tanto factores de diversa índole, cuya interacción puede ser comprendida en el marco de la teoría del encuadramiento. Los dirigentes socialistas encuadraron la actuación de las demás fuerzas políticas en una visión de la realidad en la que la insurrección socialista era la respuesta preventiva adecuada a la posibilidad de una deriva fascista de la República, porque no concebían otra alternativa: una "democracia burguesa» como la establecida en 1931 sólo podía desembocar en una dictadura de clase de uno u otro signo.

\section{BIBLIOGRAFÍA}

AVILÉS FARRÉ, Juan, 1999: La fe que vino de Rusia: la revolución bolchevique y los españoles, 19171931. Madrid. Biblioteca Nueva/UNED.

AVILÉS FARRÉ, Juan, 2006: La izquierda burguesa y la tragedia de la II República. Madrid, Comunidad de Madrid.

BERNFORD, Robert D. y SNOW, David A., 2000: «Framing processes and social movements: an overview and assessment». Annual Review of Sociology, 26.

100 El Socialista, 21-4-1934. 
BIZCARRONDO, Marta, 1975: Araquistain y la crisis socialista en la Il República. Madrid. Siglo XXI.

BIZCARRONDO, Marta, 1984: «El marco histórico de la revolución». Estudios de Historia Social, n. 31.

BIZCARRONDO, Marta, 1986: «La Segunda República: ideologías socialistas», en Juliá, S., coord.: El socialismo en España: desde la fundación del PSOE hasta 1975. Madrid. Editorial Pablo Iglesias.

CARRILLO, Santiago, 1993: Memorias. Barcelona. Planeta.

CHONG, Dennis y DRUCKMAN, James N., 2007: «Framing Theory». Annual Review of Political Science, 10.

CRUZ, Rafael, 1999: El arte que inflama: la creación de una literatura política bolchevique en España, 1931-1936. Madrid. Biblioteca Nueva.

ELORZA, Antonio y BIZCARRONDO, Marta, 1999: Queridos camaradas: la Internacional Comunista y España, 1919-1939. Barcelona. Planeta.

FONSECA, 2003: «Bibliografía sobre la revolución de octubre de 1934». Boletín del Real Instituto de Estudios Asturianos, n. ${ }^{\circ} 162$.

FUENTES, Juan Francisco, 2005: Largo Caballero: el Lenin español. Madrid, Síntesis.

GIBAJA VELÁZQUEZ, J. C., 1994: «La tradición improvisada: el socialismo y la milicia», Historia Contemporánea, 11.

GIL ROBLES, José María, 1971: Discursos parlamentarios. Madrid, Taurus.

JULIÁ, Santos, 1984: «Fracaso de una insurrección y derrota de una huelga: los hechos de octubre en Madrid». Estudios de Historia Social, n. 31.

JULIÁ, Santos, 1985: «Los socialistas y el escenario de la futura revolución», en VVAA: Octubre 1934: cincuenta años para la reflexión. Madrid, Siglo XXI.

JULIÁ, Santos, 1997: Los socialistas en la política española. Madrid. Taurus.

KOLAKOWSKI, Leszek, 1980: Las principales corrientes del marxismo, I: Los fundadores. Madrid, Alianza Editorial.

LARGO CABALLERO, Francisco, 1985: Notas históricas de la guerra en España (1917-1940). Madrid. Editorial Pablo Iglesias.

MACARRO, José Manuel, 1985: «Octubre: un error de cálculo y perspectiva», en VVAA: Octubre 1934: cincuenta años para la reflexión. Madrid, Siglo XXI.

MACARRO, José Manuel, 2001: «¿República o democracia? Las culturas obreras en la II República». En M. González de Molina y D. Caro Cancela: La utopía racional: estudios sobre el movimiento obrero español. Universidad de Granada.

MALEFAKIS, Edward 1971: Reforma agraria y revolución campesina en la España del siglo XX. BarceIona, Ariel.

MOA, Pío, 1999: Los orígenes de la guerra civil española. Madrid, Encuentro.

MONTERO, José R., 1977: La CEDA: el catolicismo social y político en la ll República. Madrid, Ediciones de la Revista de Trabajo-

POPPER, Karl, 1992: La sociedad abierta y sus enemigos. Barcelona, Planeta.

RIVAS CHERIF, Cipriano de, 1980: Retrato de un desconocido: vida de Manuel Azaña. Barcelona, Grijalbo.

ROBINSON, Richard, 1974: Los orígenes de la España de Franco. Barcelona, Grijalbo.

RUIZ, David, 1988: Insurrección defensiva y revolución obrera: el octubre español de 1934. Barcelona, Labor.

RUIZ, David, 2008: Octubre de 1934: revolución en la República española. Madrid. Síntesis.

ROSAL, Amaro del, 1983: 1934: movimiento revolucionario de octubre. Madrid, Akal.

RUIZ-MANJÓN, Octavio, 2007: Fernando de los Ríos: un intelectual en el PSOE. Madrid, Síntesis.

SEMOLINOS, Mercedes, 1985: Hitler y la prensa de la II República española. Madrid, Centro de Investigaciones Sociológicas.

SHUBERT, Adrian, 1984: Hacia la revolución: orígenes sociales del movimiento obrero en Asturias, 1860 1934. Barcelona, Crítica.

SOUTO, Sandra, 2004: ¿Y Madrid? ¿Qué hace Madrid? Movimiento revolucionario y acción colectiva. Madrid, Siglo XXI.

TORRE GÓMEZ, Hipólito de la, 1997: El Portugal de Salazar. Madrid, Arco Libros.

VIDARTE, Juan-Simeón, 1978: El bienio negro y la insurrección de Asturias. Barcelona, Grijalbo. 